\title{
Peranan Majelis Taklim Untuk Meningkatkan Kesadaran Beragama
}

\author{
St. Marwiyah \\ Institut Agama Islam Negeri Palopo \\ Jl.Agatis Balandai Kota Palopo \\ E-mail: dra_st_marwiyah@iainpalopo.ac.id
}

\begin{abstract}
The research focused on the role of the taklim assembly on the development of Bergama awareness in the community of Bara Subdistrict, with the aim of: to understand the background established by the taklim assembly in Bara Subdistrict, and to understand the activities of the taklim assembly in Bara Subdistrict, understand the role of the taklim assembly in increasing religious awareness, understand the methods the method used in the activities of the majelis taklim. This research uses descriptive qualitative method, which describes the phenomena found in the research field. In collecting data researchers used techniques; observation, interview, documentation. As for data management techniques and data analysis, researchers use; data reduction, data display, and conclusion drawing. The results showed that; majelis taklim was established in Bara Subdistrict because there are still many Muslims who still do not understand the teachings of Islam properly, majelis taklim is also active in carrying out religious activities and community activities. The researcher also found a significant role for the majelis taklim, because it could change the behavior of the members of the majelis taklim in the direction of the teachings of Islam.
\end{abstract}

Keywords: Majelis taklim; Religious awareness; Community

\begin{abstract}
Abstrak
Penelitian difokuskan pada peranan majelis taklim terhadap pengembangan kesadaran Bergama masyarakat Kecamatan Bara, dengan tujuan: (1) untuk memahami latarbelakang didirikan majelis taklim di Kecamatan Bara; (2) untuk memahami kegiatan-kegiatan majelis taklim di Kecamatan Bara; (3) untuk memahami peranan majelis taklim dalam meningkatkan kesadaran beragama, (4) untuk memahami metode-metode yang digunakan dalam kegiatan majelis taklim. Penelitian ini menggunakan metode kualitatif deskriptif, yaitu mendeskripsikan fenomena-fenomena yang ditemukan dalam lapangan penelitian. Dalam mengumpulkan data peneliti menggunakan teknik; observasi, wawancara, dokumentasi. Adapun teknik pengelolaan data dan analisis data, peneliti menggunakan; reduksi data, sajian data, dan penarikan kesimpulan. Hasil penelitian menunjukkan bahwa; majelis taklim didirikan di Kecamatan Bara karena masih banyak umat Islam yang masih kurang memahami ajaran Islam dengan baik, majelis taklim juga aktif melakukan kegiatan-kegiatan keagamaan dan kegiatan kemasyarakatan. Peneliti juga menemukan peranan majelis taklim yang signifikan, karena dapat merubah perilaku anggota-anggota majelis taklim ke arah sesuai dengan tuntunan ajaran Islam.
\end{abstract}

Kata Kunci,: Majelis taklim; Kesadaran beragama; masyarakat 


\section{Pendahuluan}

Majelis taklim adalah salah satu lembaga pendidikan Islam non formal yang sangat popular hingga saat ini. Bahkan masuknya Islam di Nusantara sekitar abad ke -7 Masehi diperkirakan lewat majelis taklim, walaupun waktu itu belum formal disebut majelis taklim. akan tetapi pertemuan dan kelompok yang dilaksanakan di masjid-masjid tergolong sebagai bentuk majelis taklim dengan melihat bentuk-bentuk majelis taklim saat ini.

Pada abad ke-13 proses pembentukan komunitas Islam berlangsung melalui kontak dagang dan perkawinan antara muballigh Islam dengan penduduk setempat. ${ }^{1}$ Dari sinilah membuktikan bahwa peran majelis taklim tidak pernah surut dalam mengembangkan kesadaran beragama secara berkesinambungan.

Keberadaan majelis taklim dengan segala aktivitasnya di Indonesia dapat dikatakan sebagai fenomena unik, mengapa, selain merupakan produk dan hasil dari kebudayaan dan peradaban yang telah dicapai oleh umat Islam di abad modern ini, lembaga ini juga berakar dari gerakan dakwah yang dilakukan oleh Rasululullah SAW dahulu. Bahkan majelis taklim telah memberikan makna tersendiri dalam dakwah dan pengembangan masyarakat serta menjadi salah satu bentuk dan cara dalam melakukan sosialisasi, internalisasi, eksternalisasi ajaran Islam, khususnya untuk kaum ibu-ibu di semua lapisan masyarakat. ${ }^{2}$

Bila dilihat dari struktur organisasinya, majelis taklim adalah termasuk organisasi pendidikan luar sekolah (non formal) yang bercirikan khusus keagamaan Islam. Bila dilihat dari segi tujuan, majelis taklim adalah termasuk lembaga atau sarana dakwah Islamiyah yang secara Self-Standing dan Self-disciplined yang dapat mengatur dan melaksanakan kegiatankegiatan, di dalamnya berkembang demokrasi yang berdasarkan musyawarah untuk mufakat demi untuk kelancaran Ta'lim Al-Islami sesuai tuntutan pesertanya. ${ }^{3}$

Majelis taklim mempunyai kedudukan dan ketentuan tersendiri dalam mengatur pelaksanaan pendidikan Islam (dakwah Islamiyah), di samping lembaga-lembaga lainnya yang mempunyai tujuan yang sama. Majelis taklim sebagai lembaga pendidikan non formal yang tidak terlalu mengikat dengan aturan yang ketak dan tetap adalah merupakan salah satu lembaga

1Saifuddin zuhri, Sejarah Kebangkitan Islam dan Perkembangannya di Indonesia, (Bandung: al-Maarif, 1998), 96.

${ }^{2}$ Tim Penyusun, Pedoman dan Silabus Majelis Ta'lim, (Jakarta : Kementerian Agama RI Direktorat Jenderal Bimas Islam Direktorat Penerangan Agama Islam, 2013), h.1

${ }^{3}$ H. M. Arifin, "Kapita Selekta Pendidikan Islam", Cet. I; Jakarta: PT. Radja Grafindo Pustaka, 1995), 4. 
pendidikan yang efektif dan efisien adalah sangat baik untuk mengembangkan potensi umat karena ia digemari masyarakat luas.

Majelis taklim diselenggarakan berbeda dengan lembaga pendidikan Islam seperti pesantren dan madrasah, baik yang menyangkut sistem, materi maupun tujuannya. Pada majelis taklim terdapat hal-hal yang cukup membedakan dengan lainnya, seperti: (1) majelis taklim adalah lembaga pendidikan non formal; (2) waktu belajarnya berkala dan teratur, tidak setiap hari sebagaimana halnya sekolah; (3) pengikut atau pesertanya disebut jama'ah (orang banyak) bukan pelajar atau santri, hal ini didasarkan kepada kehadiran majelis taklim bukan merupakan kewajiban seperti siswa menghadiri sekolah dan masyarakat; (4) tujuannya yaitu memasyarakatkan ajaran Islam. ${ }^{4}$

Majelis taklim sebagai lembaga pendidikan non formal yang sifatnya tidak terlalu mengikat dengan aturan yang ketak dan tetap merupakan lembaga pendidikan yang efektif dan efisien, cepat menghasilkan dan sangat baik meningkatkan kesadaran umat Islam karena dapat digemari oleh masyarakat luas. Efektivitas dan efisiensi sistem pendidikan majelis taklim ini sudah banyak dibuktikan melalui pengajian-pengajian Islam yang sekarang banyak tumbuh dan berkembang bukan hanya di kota-kota besar, tetapi juga berkembang di Kecamatan Bara Kota Palopo.

\section{Metode}

Metode penelitian yang digunakan dalam penelitian ini menggunakan metode kualitatif deskriptif, yaitu dengan mendeskripsikan fenomenafenomena yang ditemukan di lapangan terkait peranan majelis taklim dalam meningkatkan kesadaran beragama masyarakat.

Dalam mengumpulkan data, peneliti menggunakan teknik observasi dengan melakukan observasi terhadap kelompok-kelompok majelis taklim yang ada di Kecamatan Bara, dengan jumlah majelis taklim sebanyak 14 kelompok, melakukan wawancara dengan menggali berbagai informasi penelitian kepada informan yang terpilih, dan dokumentasi, dengan mengumpulkan data dari dokumen masyarakat dan pemerintah terkait perkembangan majelis taklim. Data yang diperolah, kemudian diolah dan dianalisis dengan menggunakan teknis analisis data yaitu reduksi data, penyajian data, dan penarikan kesimpulan.

${ }^{4}$ Hasbullah, Kapita Selekta Pendidikan Islam, Cet.1, (Jakarta: Raja Grafindo Persada, 1996), 94. 


\section{Latar Belakang Terbentuknya Majelis Taklim di Kecamatan Bara}

Pengetahuan masyarakat penganut agama Islam di Kecamatan Bara masih tergolong sangat minim. Ada sebagian diantara mereka yang masih kurang memahami ajaran Islam baik dari kalangan cendekiawan maupun dari kalangan orang-orang bukan cendekiawan. Untuk memantapkan kesadaran beragama maka harus didahului dengan pengetahuan, pemahaman serta penghayatan terhadap nilai-nilai ajaran Islam. ${ }^{5}$

Selain itu, Ny Ati menyatakan di Kelurahan Buntu Datu masih banyak penganut agama Islam yang meremehkan nilai-nilai ajaran agama Islam, padahal mereka mengaku penganut agama Islam. Hal ini dapat dibuktikan dengan masih banyaknya penganut agama Islam yang malas melakukan shalat lima waktu, baik di rumah sendiri maupun shalat berjamaah di Mesjid. Selain itu, masih banyak penganut agama Islam di Kelurahan Buntu Datu yang memiliki kemampuan untuk mengeluarkan zakat harta, juga melaksanakan qurban, tetapi mereka enggan melakukannya. ${ }^{6}$

Masalah lain yang ditimbulkan bagi orang-orang kurang memahami ajaran Islam dengan baik di Kelurahan Balandai adalah bukan hanya rusak hubungannya secara vertikal (terhadap Allah swt), tetapi juga rusak hubungannya secara horizontal (terhadap sesama manusia), misalnya; mereka kurang konsisten melakukan shalat lima waktu secara istiqamah, tidak melaksanakan puasa di bulan ramadhan secara konsisten pula, sementara hubungannya terhadap sesama manusia, juga kurang akrab, lebihlebih membantu saudara-saudaranya sesama muslim. ${ }^{7}$

Lain halnya pengakuan Ny Syamsuriati bahwa sebelum ada majelis taklim yang melakukan aktivitas keagamaan, umat Islam di Kecamatan Bara masih kurang memahami nilai-nilai ajaran agama Islam, sehingga menimbulkan sejumlah dampak negatif terhadap pengamalan agama itu sendiri. Selain kebekuan (statisme), juga pendakalan yang mengakibatkan pamor syariat Islam tidak nampak secara utuh menurut yang sebenarnya. ${ }^{8}$

Sementara menurut Haerati, bahwa masalah lain yang ditimbulkan sebagai akibat tidak adanya majelis taklim adalah kerusakan akidah, di mana kebanyakan umat Islam melakukan hal-hal yang bersifat musyrik, misalnya

${ }^{5}$ Abidah,Ketua BKMT Kecamatan Bara, Wawancara tanggal 5 Agustus 2017.

${ }^{6}$ Ati, Sekertaris BKMT Kecamatan Bara, Wawancara tanggal 22 Agustus 2017.

${ }^{7}$ Adilah Mahmud, Bendahara BKMT Kecamatan Bara, Wawancara tanggal 7 Agustus

${ }^{8}$ Syamsuriati,Wakil Ketua BKMT Kecamatan Bara, Wawancara tanggal 5 Agustus 2017. 
memohon rezeki kepada leluhurnya yang sudah meninggal dunia, percaya kepada apa yang dikatakan oleh para dukun. ${ }^{9}$

Melihat penomena-penomena di atas, maka pada tahun 1995 Ruddin mencoba mengajak para muballigh/muballighah bersama tokoh tokoh masyarakat lainnya untuk membentuk majelis taklim di setiap kelurahan, agar masyarakat Islam Kecamatan Bara dapat memahami ajaran Islam dengan baik dan mengamalkannya dalam hidup dan kehidupannya secara ikhlas, karena Allah semata-mata. ${ }^{10}$

\section{Kegiatan-Kegiatan Majelis Taklim}

Kegiatan majelis taklim di Kecamatan Bara dengan melakukan pengajian bukan hanya di lakukan di tingkat kelurahan, tetapi menyentuh sampai ke tingkat RT maupun RW. Hal tersebut sesuai dengan pendapat Ruddin, bahwa dengan adanya kegiatan pengajian Majelis Ta'lim yang dilakukan di setiap kelurahan di kota, maupun sampai ke RT dan RW, yang dilakukan oleh ibuibu kelompok majelis taklim yang di dukung oleh tim penggerak PKK Kota Palopo, bersama generasi muda di bawah koordinasi BKMT, itu sebagai usaha menanamkan pemahaman nilai-nilai agama Islam pada masyarakat guna untuk diamalkan dalam kehidupan nyata yang pada gilirannya tercipta lingkungan masyarakat yang Islami dan mengamalkannya ajaran agamanya sesuai dengan tuntunan Al-Qur'an dan sunnah Rasul SAW.11

Hal senada sebagaimana yang dikemukakan oleh Yusril Al Ikhsan bahwa dengan adanya kegiatan pengajian umum/dasar yang dilakukan di MesjidMesjid di seluruh kelurahan Kecamatan Bara, di bawah Pembina pembina majelis taklim bersama-sama tokoh-tokoh masyarakat setempat, maka kegiatan seperti itu dapat memberikan pemahaman tentang nilai-nilai syariat Islam pada masyarakat guna diamalkan dalam kehidupannya sehari-hari, sehingga mereka memperoleh kebahagiaan lahir dan bathin baik di dunia maupun di akhirat kelak. ${ }^{12}$

Sementara menurut Ny Abidah, bahwa adapun kegiatan-kegiatan majelis Taklim adalah melakukan pengajian, pengkajian, diskusi serta belajar dan melatih membaca al-Qur'an. Selain itu, juga diadakan pemberantasan buta

\footnotetext{
${ }^{9}$ Haerati, Wakil Bendahara BKMT Kecamatan Bara, Wawancara pada tanggal 10 Juli 2017.

${ }^{10}$ Ruddin, Kepala Seksi Penerangan Agama Islam Kandepag Kota Palopo, Wawancara tanggal 8 Agustus 2017.

${ }^{11}$ Ruddin, Muballigh Kota Palopo/Kasi Penerangan Agama Islam Kementerian Agama Kota Palopo, Wawancara tanggal 5 Agustus 2017

${ }_{12}$ Yusril Al Ikhsan, Muballigh Kota Palopo, Wawancara tanggal 9 Agustus2017
} 
aksara al-Qur'an terhadap ibu-ibu. ${ }^{13}$ Adapun menurut Abdul Muin Razmal, bahwa kegiatan keagamaan yang biasa dilakukan adalah menyambut harihari besar Islam, seperti; Hari Raya Idhul Fitri, Idhul Adha, Maulid Nabi Muhammad Saw., Isra' dan Mi'raj, Nuzul Qur'an dan kegiatan-kegiatan lainnya yang dianggap positif. Selanjutnya dalam kegiatan Isra' dan Mi'raj. dan Maulid Nabi Muhammad Saw selalu diawali dengan pekan ilmiah yakni; di dalamnya diadakan kegiatan ilmiah, misalnya; lomba da'i cilik, lomba adzan antara anak-anak, lomba pidato agama Islam antara remaja, dialog keagamaan dengan menghadirkan narasumber yang ahli dalam ilmu pengetahuan agama Islam, di mana kesemuanya ini diadakan dengan tujuan agar umat Islam benar-benar mengetahui, memahami, dan menghayati ajaran agama Islam secara kaffah. ${ }^{14}$

Berdasarkan observasi, ditemukan beberapa kegiatan rutin majelis taklim di berbagai Kelurahan di Kecamatan Bara sebagai berikut :

1. Kegiatan majelis taklim An Nur Kelurahan Buntu Datu

a) Melakukan pengajian rutin sebagai kegiatan pokok, hal ini dilakukan satu kali dalam sebulan dan terkadang pula mengadakan latihan belajar membaca Al-Qur'an secara bersama bagi kaum ibu, bapak dan para remaja.

b) Rajin dan giatnya para remaja dan pemuda mesjid, untuk melakukan kajian keislaman di bawah bimbingan para muballigh-muballighah

c) Mendekati umat Islam yang masih dianggap lemah imannya dengan menciptakan suasana kegemaran mereka bersama melakukan shalat berjamaah baik dimesjid maupun di rumah

d) Membaca yasinan satu kali dalam satu bulan setiap tanggal 5 pada awal bulan

e) Lomba baca doa antara anggota majelis taklim se kecamatan Bara.

f) Anggota majelis taklim berkewajiban menghafal surat-surat pendek beserta artinya agar anggota majelis taklim betul-betul dapat memahami ajaran Islam itu dengan baik. ${ }^{15}$

2. Kegiatan Majelis Taklim Nurul Ilahi Kelurahan Buntu Datu

a) Kegiatan-kegiatan keagamaan adalah aktif melakukan shalat tarwih di Mesjid setiap bulan ramadhan yang sebelumnya selalu diawali dengan ceramah-ceramah keagamaan, yang diisi dari berbagai muballighmuballigah yang boleh dikatakan diandalkan keilmuannya dalam pengetahuan agama Islam, sehingga demikian para jamaah tarwih

${ }^{13}$ Abidah Ketua BKMT Kecamatan Bara, Wawancara tanggal 5 Agustus 2017

${ }^{14}$ Abdul Muin Razmal, Muballigh, Wawancara tanggal 3 Agustus 2017

${ }^{15}$ Ratna Puji Astuti, Ketua Majelis Taklim An Nur, Wawancara tanggal 20 Agustus 
benar-benar mendapatkan pencerahan qalbu yang menuntun mereka menuju jalan yang benar menurut tutuntunan agama Islam.

b) Mengadakan pengajian dasar terhadap ibu-ibu anggota majelis taklim.

c) Mengadakan kegiatan lomba pada hari-hari benar Islam seperti cerdas cermat tentang religi dan lomba qasida rebana antara se Kecamatan Bara.

d) Mengadakan kursus perawatan jenazah agar para anggota majelis taklim dapat memberikan pelayanan yang maksimal terhadap sesama umat Islam yang mengalami kematian.

e) Mengadakan silaturrahmi dari rumah ke rumah yang dirangkaikan dengan arisan. ${ }^{16}$

3. Kegiatan Majelis Taklim Al Jihad Kelurahan Tamalebba

a) Melakukan pembinaan pengajian dasar terhadap anak-anak setiap malam, juga diadakan pemberantasan buta aksara, al-Qur'an terhadap ibu-ibu maupun bapak-bapak yang belum tahu sama sekali membaca al Qu'an.

b) Mengaktifkan ceramah-ceramah setiap bulan ramadhan dengan cara mendatang muballigh-muballighah, dan itu dilaksanakan antara shalat dengan shalat tarwih.

c) Selalu mengadakan pengajian yang sifatnya umum satu kali dalam satu bulan yaitu setiap tanggal 5 di awal bulan.

d) Mengadakan tadarrus al Qur'an satu kali dalam satu bulan.

e) Membaca yasinan dua kali dalam satu yaitu pada jumat pertama diawal bulan dan jumat terakhir di akhir bulan. ${ }^{17}$

4. Kegiatan majelis taklim Al Khaerat Kelurahan Balandai

a) Melakukan pengajian dasar secara rutin pada malam hari yaitu antara shalat magrib dan isya terhadap anak usia sekolah dasar ke bawah.

b) Aktif melakukan ceramah-ceramah keagamaan setiap bulan ramadhan

c) Melakukan pelatihan-pelatihan muballigh menjelang masuk bulan ramadhan terhadap para remaja mesjid, supaya begitu tiba waktunya ramadhan maka ceramah-ceramah tarwih dapat aktif sesuai dengan harapan bersama.

d) Aktif melakukan yasinan setiap bulan yaitu setiap tanggal 10 di awal bulan.

e) Melaksanakan pembacaan barasanji setiap ingin melakukan acaraacara yang sifatnya ritual misalnya; pada acara perkawinan maupun pada cara manasik haji bagi mau naik haji.

f) Aktif mengadakan gotong royong dalam membersihkan lingkungan. ${ }^{18}$

16Kastini, Ketua Majelis Taklim Nurul Ilahi, Wawancara tanggal 24 Agustus 2017

17 Syamsuriati, Ketua Majelis Taklim Al Jihad, Wawancara tanggal 26 Agustus 2017 
5. Kegiatan majelis taklim Jabal Nur Kelurahan Rampoang

a) Mengadakan pengajian rutin setiap bulan, dan tanggal pelaksanaanya berdasarkan kesepakatan dengan sesama angggota majelis taklim.

b) Mengadakan pembacaan al Qur'an secara bergilir satu kali dalam bulan, kemudian ada salah seorang ahli qiraah yang mengoreksi bacaannya, setelah mereka membaca al Qur'an secara bergiliran.

c) Mengadakan ajangsana ke Panti Asuhan setiap bulan rahmadhan. ${ }^{19}$

6. Kegiatan majelis taklim Nurul Wustha Kelurahan To'bulung

a) Mengadakan pembacaan surah yasin, surah al Waqiah, dan surah Tabarak setiap malam jumat.

b) Mengadakan pengajian rutin setiap bulan, yaitu pada setiap awal bulan dan sekaligus arisan.

c) Mengadakan zikir bersama pada waktu-waku yang disepakati satu kali dalam satu bulan. ${ }^{20}$

Berdasarkan wawancara dan pengamatan langsung, maka kegiatan majelis taklim diberbagai Kelurahan di Kecamatan Bara ada dua, yaitu ada bersifat keagamaan dan ada yang bersifat kemasyarakatan.

\section{Peranan Majelis Taklim Dalam Meningkatkan Kesadaran Beragama di Kecamatan Bara}

Berdasarkan pengamatan langsung dan wawancara dengan ketuaketua majelis taklim, bahwa ada perbedaan yang mendasar sebelum dan sesudah didirikan majelis taklim diberbagai Kelurahan di Kecamatan Bara sebagai berikut :

${ }^{18} \mathrm{Hj}$. Mardewi, Ketua Majelis Taklim Al Khaerat, Wawancara tanggal 25 Agustus

${ }^{19}$ Kartini Alwi, Ketua Majelis Taklim Jabal Nur, Wawancara pada tanggal 28 Agustus 2017

${ }^{20} \mathrm{Hj}$.Fatimah, Ketua Majelis Taklim Nurul Wustha, Wawancara pada tanggal 30 Agustus 2017 
Tabel 1. Perbedaan Sebelum dan Sesudah Pendirian Majelis Taklim

\begin{tabular}{|c|c|c|}
\hline No & $\begin{array}{l}\text { Sebelum Didirikan } \\
\text { Majelis taklim }\end{array}$ & $\begin{array}{l}\text { Sesudah Didirikan } \\
\text { Majelis taklim }\end{array}$ \\
\hline 1 & $\begin{array}{l}\text { Masjid belum ramai dikunjungi } \\
\text { ibu-ibu setiap pelaksanaan } \\
\text { shalat lima waktu. }\end{array}$ & $\begin{array}{l}\text { Masjid ramai dikunjungi ibu-ibu } \\
\text { setiap pelaksanaan lima waktu. }\end{array}$ \\
\hline 2 & $\begin{array}{l}\text { Ibu-ibu belum memakai jilbab } \\
\text { setiap keluar rumah }\end{array}$ & $\begin{array}{l}\text { Pada umum ibu-ibu memakai jilbab } \\
\text { setiap keluar rumah. }\end{array}$ \\
\hline 3 & $\begin{array}{l}\text { Ibu-ibu belum banyak yang } \\
\text { dapat membaca al Qur'an. }\end{array}$ & $\begin{array}{l}\text { Pada umumnya ibu-ibu sudah yang } \\
\text { dapat membaca al Qur'an dengan } \\
\text { baik. }\end{array}$ \\
\hline 4 & $\begin{array}{l}\text { Kebanyakan ibu-ibu belum } \\
\text { menghafal bacaan shalat dengan } \\
\text { baik. }\end{array}$ & $\begin{array}{l}\text { Kebanyakan ibu-ibu sudah } \\
\text { menghafal bacaan shalat dengan } \\
\text { baik. }\end{array}$ \\
\hline 5 & $\begin{array}{lrr}\text { Kebanyakan ibu-ibu } & \text { belum } \\
\text { mengeluarkan zakat } & \text { fitrah, } \\
\text { apalagi zakat harta. } & \end{array}$ & $\begin{array}{l}\text { Kebanyakan ibu-ibu memiliki } \\
\text { kesadaran yang tinggi dalam } \\
\text { mengeluarkan harta,apalagi zakat } \\
\text { fitrah. }\end{array}$ \\
\hline 6 & $\begin{array}{llr}\text { Kebanyakan } & \text { ibu-ibu mudah } \\
\text { menceritakan } & \text { kejelekan } & \text { orang } \\
\text { lain. } & & \\
\end{array}$ & $\begin{array}{l}\text { Ibu-ibu sudah tidak mudah } \\
\text { menceritkan kejelekan orang lain. }\end{array}$ \\
\hline 7 & $\begin{array}{lr}\text { Kebanyakan } & \text { ibu-ibu } \\
\text { mengunjungi dukun-dukun } \\
\text { untuk menanyakan persoalan } \\
\text { nasibnya. }\end{array}$ & $\begin{array}{l}\text { Ibu-ibu tidak lagi mengunjungi } \\
\text { dukun-dukun untuk menanyakan } \\
\text { persoalan nasibnya. }\end{array}$ \\
\hline 8 & $\begin{array}{l}\text { Kebanyakan ibu-ibu membakar } \\
\text { kemenyan pada saat memasuki } \\
\text { bulan puasa dan menyiapkan } \\
\text { nasi dengan lauk pauk, yang } \\
\text { tujuan untuk memberikan } \\
\text { makan kepada leluhur. }\end{array}$ & $\begin{array}{l}\text { Kebanyakan ibu-ibu tidak lagi } \\
\text { melakukan perbuatan-perbuatan } \\
\text { syirik seperti itu. }\end{array}$ \\
\hline 9 & $\begin{array}{l}\text { Kebanyakan Ibu-ibu kurang } \\
\text { menyantuni anak-anak yatim. }\end{array}$ & $\begin{array}{l}\text { Kebanyakan ibu-ibu suka } \\
\text { menyantuni anak yatim. }\end{array}$ \\
\hline 10 & $\begin{array}{l}\text { Kebanyakan ibu-ibu } \text { kikir } \\
\text { memberi sumbangan } \\
\text { pembangunan mesjid. }\end{array}$ & $\begin{array}{l}\text { Kebanyakan ibu-ibu senang sekali } \\
\text { memberi sumbangan kepada } \\
\text { pembangunan mesjid. }\end{array}$ \\
\hline 11 & $\begin{array}{lcr}\text { Kebanyakan } & \text { ibu-ibu tidak } \\
\text { mengundang buka bersama di } \\
\text { rumahnya } & \text { setiap bulan } \\
\text { ramadhan. } & & \\
\end{array}$ & $\begin{array}{l}\text { Kebanyakan ibu-ibu mengundang } \\
\text { buka bersama di rumahnya setiap } \\
\text { bulan ramadhan. }\end{array}$ \\
\hline 12 & $\begin{array}{l}\text { Kebanyakan ibu-ibu belum } \\
\text { banyak mengunjungi panti } \\
\text { asuhan di bulan ramadhan, } \\
\text { apalagi di luar bulan ramadhan. }\end{array}$ & $\begin{array}{l}\text { Kebanyakan ibu-ibu suka } \\
\text { mengunjungi panti asuhan bukan } \\
\text { hanya dalam bulan ramadhan, } \\
\text { tetapi juga di luar bulan ramadhan. }\end{array}$ \\
\hline 13 & Kebanyakan ibu-ibu belum & Pada umumnya ibu-ibu sudah \\
\hline
\end{tabular}




\begin{tabular}{|c|l|ll|}
\hline & $\begin{array}{l}\text { dapat melakukan perawatan } \\
\text { jenazah dengan cara Islami. }\end{array}$ & $\begin{array}{l}\text { dapat merawat jenazah dengan } \\
\text { cara Islami. }\end{array}$ \\
\hline 14 & $\begin{array}{l}\text { Kebanyakan ibu-ibu masih } \\
\text { enggan membantu kaum dhuafa. }\end{array}$ & $\begin{array}{l}\text { Kebanyakan ibu-ibu ringan tangan } \\
\text { membantu kaum dhuafa. }\end{array}$ \\
\hline 15 & $\begin{array}{l}\text { Ibu-ibu jarang } \\
\text { melaksanakan shalat sunnat } \\
\text { rawatib. }\end{array}$ & $\begin{array}{l}\text { Pada umumnya ibu-ibu senang } \\
\text { melaksanakan shalat sunnat } \\
\text { rawatib. }\end{array}$ \\
\hline
\end{tabular}

Sumber ; Data Olahan Penelitian

\section{Metode-Metode Pembelajaran Pada Majelis Taklim di Kecamatan Bara}

Metode yang digunakan dalam kegiatan pembelajaran pada Majelis Taklim diberbagai Kelurahan di Kecamatan Bara adalah sebagai berikut :

1. Metode Ceramah

Metode ceramah umummnya dikenal di kalangan masyarakat sebagai teknik dakwah yang banyak diwarnai oleh ciri karakteristik bicara oleh seorang da'i atau muballigh yang melakukan aktivitas dakwah. ${ }^{21}$

Ceramah yang baik dapat menarik perhatian dan mampu merubah sikap dan pola pikir pandangan masyarakat (audiensinya), metode ceramah sebagai salah satu teknik berdakwah atau kemampuan dan kemahiran berbicara atau seni berbicara. Hal ini biasa dikenal dengan retorika dakwah. Dakwah tidak akan berhasil tanpa seni dalam menyampaikan suatu seruan atau panggilan kepada seseorang untuk berbuat dan beramal. Maka retorika merupakan seni dalam berbicara, sebagaimana dikatakan Aristoteles. Retorika adalah "The art of persuasion", artinya ilmu kepandaian berpidato atau teknik dan seni berbicara di depan umum. ${ }^{22}$

2. Metode,Tanya Jawab

Metode tanya adalah merupakan cara para muballigh-muballighah untuk melayani peserta majelis taklim dengan kebutuhannya, sebab dengan bertanya berarti peserta majelis taklim ingin mengerti ajaran Islam supaya mereka dapat mengamalkannya dalam kehidupan seharihari.

Metode tanya sangat cocok dan efektif dipergunakan dalam kegiatan dan kemasyarakatan seperti halnya pada acara diskusi, pengajian dan semacamnya. Metode ini sangat berguna untuk mengurangi

${ }^{21}$ Asmuni Syukir, Dasar-Dasar Strategi Dakwah Islam, (Surabaya: Al-Ikhlas,1998), 104

${ }^{22}$ A. H. Hasanuddin, Retorika Dakwah dan Publistik dalam Kepemimpinan, (Surabaya: Usaha Nasional, 1982),5 
kesalapahaman para pendengar khalayak, menjelaskan perbedaan pendapat, menerangkan hal-hal yang belum dimengerti. ${ }^{23}$

Metode tanya jawab tidak berjalan satu arah atau one way communication seperti ceramah tapi berjalan dua arah atau two way communication dalam artian ada feed back atau umpan balik antara peserta majelis taklim dengan muballigh. ${ }^{24}$

Dari pendapat para muballigh di atas dapat dipahami, bahwa metode, tanya jawab merupakan metode yang efektif pula, di mana komunikasinya berjalan dua arah yakni; ada umpan balik atau feed back antara muballigh dengan peserta majelis taklim.

3. Metode Latihan

Pada metode latihan atau percontohan ini sangat bagus diterapkan di Majelis taklim, dalam rangka memberi pemahaman agama Islam terhadap umat Islam secara umum dan khususnya peserta majelis taklim Kecamatan Bara, metode latihan ini adalah salah satu cara atau usaha yang ditempuh oleh para muballigh-muballighah dalam memberi pengajian kepada peserta majelis taklim. ${ }^{25}$

Pada metode latihan/percontohan ini sering dilakukan oleh para muballigh-muballighah terdahulu, sebab Nabi saw. sering menggunakan metode percontohan ini, di mana disebutkan dalam suatu hadis sebagai berikut:

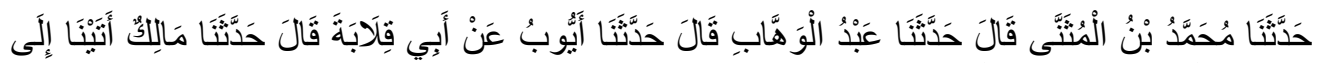

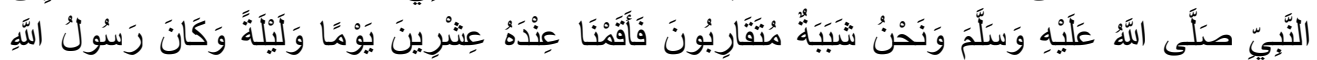

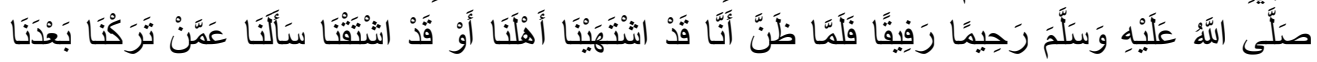

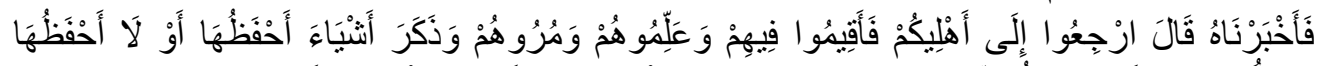

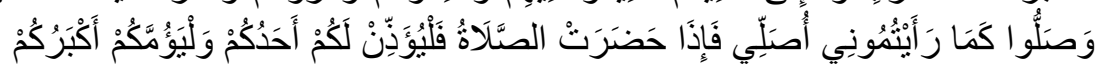

Telah menceritakan kepada kami Muhammad bin Al Mutsanna berkata, telah menceritakan kepada kami 'Abdul Wahhab berkata, telah menceritakan kepada kami Ayyub dari Abu Qilabah berkata, telah menceritakan kepada kami Malik, "Kami datang menemui Nabi shallallahu 'alaihi wasallam, saat itu kami adalah para pemuda yang usianya sebaya. Maka kami tinggal bersama beliau selama dua puluh hari dua puluh malam. Beliau adalah seorang yang sangat penuh kasih dan lembut. Ketika beliau menganggap bahwa kami telah ingin, atau merindukan keluarga kami, beliau bertanya kepada kami tentang orang

${ }^{23}$ Siwan Rifai, Muballigh Kota Palopo, Wawancara, tanggal 6 Agustus 2017.

${ }^{24}$ Yusril Al Ikhsan, Muballigh Kota Palopo, Wawancara tanggal 9 Agustus 2017.

${ }^{25}$ Solihatin, Muballighah Kota Palopo, Wawancara tanggal, 8 Agustus 2017. 
yang kami tinggalkan. Maka kami pun mengabarkannya kepada beliau. Kemudian beliau bersabda: "Kembalilah kepada keluarga kalian dan tinggallah bersama mereka, ajarilah mereka dan perintahkan (untuk shalat)." Beliau lantas menyebutkan sesuatu yang aku pernah ingat lalu lupa. Beliau mengatakan: "Shalatlah kalian seperti kalian melihat aku shalat. Maka jika waktu shalat sudah tiba, hendaklah salah seorang dari kalian mengumandangkan adzan, dan hendaklah yang menjadi Imam adalah yang paling tua di antara kalian."26

Metode pelatihan atau percontohan tersebut, juga merupakan cara yang baik untuk memperlihatkan kepada para peserta majelis taklim agar lebih jelas, sehingga dapat dipahami dan diamalkan dalam kehidupan sehari-hari.

4. Metode Silaturrahmi

Metode silaturrahmi merupakan metode majelis taklim yang dirasa efektif juga dalam rangka membina kelompok-kelompok majelis taklim, agar mereka dapat memahami ajaran agamanya dengan baik.

Dalam metode silaturrahmi para peserta majelis taklim saling terbuka dan mereka bebas berbicara antara satu dengan yang lain dalam segala persoalan terutama masalah-masalah agama maupun yang menyangkut kemasyarakatan. Metode ini sangat baik karena dapat memperkuat persaudaraan, memperkokoh rasa cinta dan kasih sayang antara sesama manusia, saling tukar menukar pikiran dan pengalaman. Dan bila ada suatu keganjilan atau suatu persoalan yang butuh pernecahan, maka langsung dipecahkan atau diselesaikan pada saat itu juga, sehingga mudah diterima oleh semua orang, ini berarti dapat meningkatkan pemahaman umat Islam terhadap ajaran agamanya. ${ }^{27}$

Dalam buku "Dasar-Dasar Strategi Dakwah Islam", bahwa metode silaturrahmi dapat dilakukan dengan dengan dua cara sebagai berikut :

1) Atas undangan tuan rumah, cara ini biasanya tuan rumah sudah memeluk agama Islam, namun mereka secara sadar berminat untuk memperdalam keislamannya, dengan kata lain cara ini bersifat pembinaan umat Islam.

2) Atas kehendak da'i, biasanya metode ini dilakukan da'i bilamana obyek dakwahnya belum memeluk agama Islam diajak agar mereka

${ }^{26}$ Bukhari, Shahih al-Bukhari, dalam CD Hadis Lidwa Pusaka i-Softwere-Kitab 9 Imam Hadis.

${ }^{27}$ Adilah Mahnmud, Muballighah, Wawancara tanggal 11 Agustus 2017. 
sadar memeluk agama Islam, dengan kata lain cara ini bersifat pengembangan umat Islam. ${ }^{28}$

Metode silaturrahmi mempunyai peranan ganda, karena di samping membina pemahaman agama umat Islam juga dapat mengembangkan umat Islam.

Dengan adanya kegiatan majelis taklim yang berisikan materi; aqidah, syari'ah, dan akhlak al karimah dengan menggunakan metode ceramah, tanya jawab, latihan (drill) dan silaturrahmi, maka pengetahuan dan pemahaman ajaran para peserta majelis taklim masyarakat Kecamatan Bara terhadap ajaran agamanya banyak mengalami kemajuan yang signifikan.

\section{Kesimpulan}

Majelis Taklim adalah suatu komunitas muslim yang secara khusus menyelenggarakan pendidikan dan pengajaran tentang agama Islam, Majelis Taklim dikenal diberbagai tempat dengan istilah yang berbeda-beda, seperti pengajian umum, taman pendidikan al-Qur'an untuk anak-anak, juga pengajian dasar bagi orang dewasa belum tahu membaca al Qur'an, dan sebagainya, tujuan dari semua itu adalah untuk memberikan bimbingan kepada umat Islam agar mereka mengetahui, memahami dan mengamalkan ajaran agamanya. Lahirnya kelompok majelis taklim diberbagai Kelurahan di Kecamatan Bara Kota Palopo dilatarbelakangi oleh berbagai faktor diantaranya masih banyaknya penganut agama Islam yang masih acuh tak acuh terhadap ajaran agamanya, banyak yang melakukan penyimpangan dari ajaran agama seperti syirik, melakukan hal-hal yang sifatnya bid'ah serta sikap taklid kepada orang-orang yang tidak memahami syariat Islam yang sesungguhnya. Kegiatan majelis diberbagai Kelurahan di Kecamatan Bara secara umum ada dua yaitu; kegiatan yang bersifat keagamaan dan kegiatan yang bersifat kemasyarakatan. Dalam meningkatkan pengetahuan, pemahaman dan pengamalan umat Islam kecamatan Bara adalah tidak terlepas dari penguasaan materi, metode, serta keteladanan yang diterapakan oleh pelaku dakwah, sehingga dengan demikian para peserta Majelis Ta'lim dengan mudah mengetahui, memahami dan. mengaplikasikan ajaran agama itu dengan sebaik-baiknya sesuai dengan tuntutan ajaran agama.

${ }^{28}$ Asmuni Syukir, Dasar-Dasar Strategi Dakwah Islam, (Surabaya: Al-Ikhlas,1998), 162. 


\section{Daftar Pustaka}

Abdul Goffar, Asyhari, 1996. Sekelumit Tentang Aqidah Islam, Cet. I (Jakarta: Bumi Aksara).

Departemen Agama R.I, 1983. Al-Qur'an dan Terjemahnya, (Jakarta: Proyek Pengadaan Kitab Suci Al-Qur'an).

Darajat, Zakiah, dkk, 1984. Dasar-Dasar Agama Islam, (Jakarta: Bulan Bintang).

Hasanuddin, A.H, 1982. Retorika Dakwah dan Publistik dalam Kepemimpinan, (Surabaya: Usaha Nasional).

Hasbullah, 1996. Kapita Selekta Pendidikan Islam, Cet.1, (Jakarta: Raja Grafindo Persada).

Hasan, Mohammad Tholchah, 2002. Metode Penelitian Kualitatif, (Malang: Lembaga Penelitian Universitas Negeri Malang).

H. M. Arifin, 1995. Kapita Selekta Pendidikan Islam, Cet. I, (Jakarta: PT. Radja Grafindo Pustaka).

IKIP Malang, 1997. Dasar-Dasar Metodologi Penelitian, (Malang: Lembaga Penelitian IKIP Malang).

Nata, Abuddin, 2011. Studi Islam Komprehenshif, Cet.I, Jakarta: Kencana).

Razak, Nasaruddin, 1983. Dienul Islam, Cet. II, ( Bandung: PT. al Ma'arif).

Saifuddin Zuhri, 1998. Sejarah Kebangkitan Islam dan Perkembangannya di Indonesia, (Bandung: al-Maarif).

Sanusi Salahuddin 1994. Pembahasan Sekitar Prinsip-Prinsip Dakwah, (Semarang: Ramadhan).

Sugiyono, 2009. Metode Penelitian Kuantitatif, Kualitatif d R \& D, Cet.VI, (Bandung: Alfabeta).

Sugiyono,2016. Memahami penelitian kualitatif, Cet.12, (Bandung: Alfabeta). Syukir, Asmuni, 1998. Dasar-Dasar Strategi Dakwah Islam, (Surabaya: AlIkhlas).

Sayid Sabiq, 1972. Aqidah Islam, Cet. II, (Bandung: CV. Diponegoro).

Tim Penyusun, 2013. Pedoman dan Silabus Majelis Ta'lim, (Jakarta :Kementerian Agama RI Direktorat Jenderal Bimas Islam Direktorat Penerangan Agama Islam).

Ya'kub, Hamzah, , 1983. Etika Islam, Cet. VI, ( Bandung: CV. Diponegoro). 